\title{
HARMONIZATION OF ISLAMIC LAW IN NATIONAL LEGAL SYSTEM: A COMPARATIVE STUDY BETWEEN INDONESIAN LAW AND MALAYSIAN LAW
}

\author{
Yeni Salma Barlinti ${ }^{1}$
}

\begin{abstract}
This article compares Indonesia legal system and Malaysian legal system. The government legalized Islamic law in national legislations, which are in effect for Muslim people. To facilitate dispute settlement, there is a religious court to solve Islamic dispute based on Islamic law. The existence of Islamic law in Indonesia and Malaysia has similarity and differentiation. The similarties among others are: the Muslim-majority in both countries pushes the government to put Islamic law into force, Islamic law must be written into constitution or legislation. It is needed to have legal basis when performing Islamic law, the existence of religious court is very important in dispute settlement related to Islamic law. The influence of western legal system is very strong in national legal system. Nevertheless, the western legal system differs substantially from Islamic legal system, and Islamic law was implemented limitedly based upon western legislation. It was limited to family law. While the differentiations are: the way of implementation of western legal system into national legal system and the form of legislation. Indonesia has one legislation, which is in effect to all of Indonesia people. On the contrary, Malaysia has many enactments, which are different from one to another in each negeri.
\end{abstract}

Keywords: Indonesia, Malaysia, Islamic law, Legal systems, Comparative study.

\section{Introduction}

Islamic law is the law regulates many fields. This law in some countries has become legal system such as Egypt and Saudi Arabia, but in others it is just part of national legal system. At the latter, Indonesia and Malaysia were countries use Islamic Law as part of national legal system. It can be seen in national legislations and court system. The government legalized Islamic law in national legislations, which are in effective for Muslim people. To facilitate dispute settlement, there is religious court to solve Islamic dispute based on Islamic Law.

I make comparison between Indonesian legal system and Malaysian legal system due to some reasons. First, Indonesia and Malaysia has Muslim-majority citizen. Indonesia as the world's largest Muslim-majority country has 87.2\% Muslim

\footnotetext{
${ }^{1}$ Lecturer of Islamic Law at Faculty of Law, Universitas Indonesia. The author can be contacted at barlintiyesa@yahoo.com.
} 
people in $2005 .^{2}$ In Malaysia, the proportion of Muslim people was $60.4 \%$ based on census $2000 .^{3}$ Second, as occupied countries, law of colonial country affected national legal system. In a very long time, 350 years approximately, some countries, such as Netherlands, Portugal, and Japan occupied Indonesia; Netherlands was the longest colonial country. The most influential law to Indonesian legal system is Dutch Law. Burgerlijk Wetboek is used until now. On the other side, some countries, such as Portugal, Netherlands, and England, occupied Malaysia as well. Third, before occupied, Islam had come into both countries. The influential Islamic teaching was so strong. Therefore, the people converted to be Muslim. The Muslim people in both countries had obeyed Islamic law and had religious court to dispute settlements based on Islamic law.

Islamic law was the general law of the Malay states until the advent of British rule in the late nineteenth century, when the Malay Rulers accepted British Residents as advisors, but retained control over matters relating to Islam and Malay custom. ${ }^{4}$

And the last, currently, Islamic law is legalized nationally to be in effective in both countries.

\section{A. Characteristic of Society}

Indonesia is divided to more than 30 provinces, increased from 27 provinces. Among provinces, there are many races or suku who has different traditional system from one to the others. Therefore, there are many custom laws live in Indonesia. Besides, there are six religions embraced by Indonesian people, i.e., Islam, Catholic, Protestant, Hindu, Buddha, and Kong $\mathrm{Hu} \mathrm{Cu}$, the latter is the officially recognized religion by the government. From those religions, Islam is the majority-followed religion. Based on Number of Population by Religion Year 2005 published by Religious Department Republic of Indonesia, the religious composition is Islam 87.2\%, Christian $6.2 \%$, Catholic 3.3\%, Hinduism 2.2\%, and Buddhism $1.1 \% .^{5}$ (There is no data for the composition of Kong Hu Cu followers).

In Malaysia, the amount of population in 2006 is 25,399,213 persons. ${ }^{6}$ Based on population and housing census 2000, the ethnic composition of population in 2000 (23.27 million) is

Of the total population of Malaysia in Census 2000, about 21,890 thousand or 94.1\% were Malaysian citizens. Of the total Malaysian citizens, Bumiputera

\footnotetext{
2 "Number of Population Religion Year 2005", http://www.depag.go.id/index.php?menu=page\&pageid=17, accessed on March 2nd 2006.

${ }^{3}$ Population and Housing Census 2000 in Press Statement, "Population Distribution and Basic Demographic Characteristics Report Population and Housing Census 2000", Putrajaya $6^{\text {th }}$ November 2001, http://www.statistic.gov.my/english/census/pressdemo.htm , accessed February 28th 2006.

${ }^{4}$ Mohammad Hashim Kamali, Islamic Law in Malaysia: Issues and Developments, (Kuala Lumpur: Ilmiah Publishers, 2000), p. 6.

5 "Number of Population by Religion Year 2005", loc.cit.

${ }^{6}$ http://www.statistics.gov.my/english/frameset product.php?file=list\&id=population
} 
comprised $65.1 \%$, Chinese $26 \%$ and Indians $7.7 \%$, the ethnic composition being $60.6 \%, 28.1 \%$ and $7.9 \%$ respectively in 1991. Non-Malaysian citizens totalled 1,385 thousand (or 5.9\%) in Census 2000 as against 805 thousand (or 4.4\%) in $1991 .^{7}$

The ethnicity has correlation with the religion. Based on statistic of religion in 2000,

Islam was the most widely professed religion in Malaysia; its proportion increasing from 58.6\% in 1991 to 60.4\% in 2000. Malaysia, being a multi-religious such as Buddhism (19.2\%), Christianity (9.1\%), Hinduism (6.3\%) and Confucianism/ Taoism/other traditional Chinese religion (2.6\%) as revealed in Census 2000. ${ }^{8}$

In Islamic teaching, the follower is not only taught matter related to God, but also matter related to individual, society, government, things, and nature. The teaching is not only about religion itself, but also about others fields, such as law, economics, social, pedagogic, medicine, etc. In law matter, the Muslim people have to obey regulation about marriage, divorce, heritage, contract, judicature, etc. Thus, we can see how the Muslim people practice Islamic law. This practice is still running even no regulated officially, because the root of law is in al-Qur'an, the Islamic Holly Book, and as-Sunnah, words, deeds and silence of the prophet Muhammad (peace and blessings of Allah be upon him).

On this paper I try to describe and analyze harmonization of Islamic law to national legal system, comparison between Indonesia and Malaysia. Discussion about religious court is as effect of stimulated problems in society solely.

\section{B. Problem Identification}

As the ones who admit Islam as their religion, the Muslim people have a mustobligation to obey the law of God. This obligation is written in al-Qur'an (Islamic Holy Book) at surah An Nisa (4) verse 59,

O ye who believe! Obey God, and obey the Apostle, and those charged with authority among you. If ye differ in anything among yourselves, refer it to God and His Apostle, if ye do believe in God and the Last Day: That is best, and most suitable for final determination. ${ }^{9}$

And surah An Nur (24) verse 51,

The answer of the Believers, when summoned to God and His Apostle, in order that He may judge between them, is no other than this: they say, "We hear and we obey". It is such as these that will attain felicity. ${ }^{10}$

${ }^{7}$ Population and Housing Census 2000. loc.cit.

${ }^{8}$ Ibid.

9 'Abdullah Yusuf 'Ali, The Holy Qur'an: Text and Translation, $5^{\text {th }}$ reprint, (Kuala Lumpur: Islamic Book Trust, 2003), p. 78.

${ }^{10}$ Ibid., p. 341. 
In al-Qur'an, the God states the purpose of this obligation is to getting happiness in the next world. It is stated at surah An Nur (24) verse 52,

It is such as obey God and His Apostle, and fear God and do right, that will win (in the end). ${ }^{11}$

They will have consequences, if they do not obey the law of God, as stated in surah An Nisa (4) verse 14,

But those who disobey God and His Apostle and transgress His limits will be admitted to a Fire, to abide therein: And they shall have a humiliating punishment. ${ }^{12}$

As citizen, they have obligation to obey the law of state also. There could be contradiction when the law of state is different from the law of God. In one side, if the Muslim people do not obey the law of God they will be sinner; hell is their punishment in the next world. On the other side, if they do not obey the law of state they will get sanction or punishment. Regarding to this problem, it needs to harmonize Islamic law in national legal system. This implementation of harmonization will be learned and analyzed in Indonesian and Malaysian legal system.

\section{Theory of the Effectiveness of Islamic Law}

In Islamic teaching, there are inseparable elements, i.e., akidah, syariah, and akhlak as the base of the teaching. Akidah (tauhid) is faith or believe as foundation or life guidance of Muslim. The faith or iman relates to the Oneness of God. Syari'ah is set of norm of God determines relationship between human and God, human and society, human and things, human and environment. This element explains how to make connection to God (ibadat), such as shalat (pray) or haj, and how to make relationship to society, things, and environment (muamalat), such as social, politics, economics, law, education, etc. Akhlak is behaviour, character to God (tasawuf) and to creatures (ethics or morality). ${ }^{13}$

Muhammad Tahir Azhary pointed out his circle of concentric theory related to relationship of religion, law, and state. In Islamic concept, religion, law, and state are a unity and have close relationship. The relationship forms circle of concentric. The inner circle is religion as core of the circle. The second one is law. The religion circle has big influence to the law circle. Religion is a foundation and a main source of law. In the law, there are three inseparable elements of Islamic teaching, i.e., tauhid, syari'ah, and akhlak (as mentioned above). Therefore, the law contains not only normative rule, but also morality. The outer circle is state contains religion and law. It means that the role of religion is very important in the law and the state. He confirmed that the last

\footnotetext{
11 Ibid.

12 Ibid., p. 71.

${ }^{13}$ Mohammad Daud Ali, Hukum Islam: Pengantar Ilmu Hukum dan Tata Hukum Islam di Indonesia, (Jakarta: RajaGrafindo Persada, 2000), pp. 29-36.
} 
circle (the state) does not mean that the state besieges or surrounds the law and the religion. ${ }^{14}$

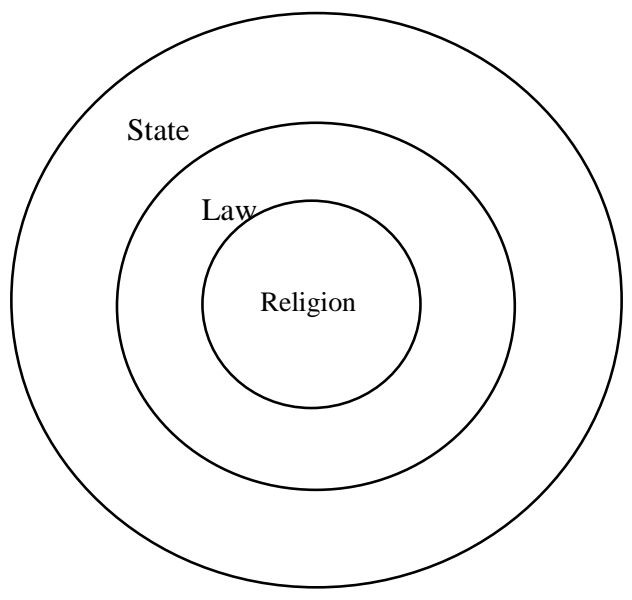

HAR Gibb points in The Modern Trends in Islam that if Muslim people accept Islam as their religion, they accept Islamic legal authority towards themselves. ${ }^{15}$ Islamic law as a part of Islamic teaching has been absorbed to Muslim society, because they obey and do the law. The obedience is due to the creator of the law is God who creates human. It describes that God is superior to human. Therefore, the Muslim people accept the power of Islam. Ichtijanto considered these Gibb's thought as a theory. It is named "theory of legal authority reception".

In Islam, there were extents to put the law into force. This matter based on situation and condition of society, called tasyrik. For instance, prohibition of khamr or alcoholic drink was through some extents. Firstly, the warning of prohibition of khamr was reminding that there were good and bad effects but the bad ones were bigger than the good ones (surah al Baqarah verse 219). So, it is a sin. Secondly, the prohibition of drinking khamr was stated if Muslim would like to pray (surah an Nisa verse 43). It was given when the faith of Muslim people was better. And the last, the hard commands were intoxicants, gambling, dedication of stones, and divination by arrows, are abomination, evil's handwork, they must eschew them all (surat al Maidah verse 90). On this extent, the faith of Muslim was getting better and better. ${ }^{16}$

Another way to put Islamic law into force is by taklif. Taklif is a policy to put the law towards human as mukallaf (legal subject) by considering situation and condition of the private subject; considering the physical and spiritual ability, having freedom and common sense. ${ }^{17}$

14 Muhammad Tahir Azhary, Negara Hukum: Suatu Studi tentang Prinsip-prinsipnya Dilihat dari Segi Hukum Islam, Implementasinya pada Periode Negara Madinah dan Masa Kini, (Bogor: Kencana, 2003), pp. 67-68.

${ }^{15}$ Ichtijanto SA, Hukum Islam dan Hukum Nasional, (Jakarta: Ind-Hill Co, 1990), p. 23.

16 Ibid., p. 11.

17 Ibid. 
The enactment of Islamic law cannot be separated from divine law which written in al-Qur'an and determination of prophet Muhammad (peace and blessing of Allah be upon him) in al-Hadits. For some material, Islamic law only determines principles of subjects, such as prohibition of riba or interest, prohibition of cheating in trading or purchasing in economics law. For other material, Islamic law determines subjects in detail. For instance, determination of marriage, divorce, and heritage. Therefore, ratio (' $a q l$ ) can be used to compose the enactment in implementing legal enforcement in society. The implementation should heed the base of Islamic teaching and the way to form law in society, by noticing custom law for example. The most important thing is the enactment does not contradict with the divine law in al-Qur'an and al-Hadits.

\section{Legal System}

Sudikno Mertokusumo defines the legal system as the following.

Sistem hukum adalah suatu kesatuan yang terdiri dari unsur-unsur yang mempunyai interaksi satu sama lain dan bekerja sama untuk mencapai tujuan kesatuan tersebut. ${ }^{18}$

[Legal system is a unity consists of elements interact from one to the others and cooperate to accomplish the unity].

This legal system as unity divided into parts. These parts have certain criterion to be fulfilled, such as materiel law-formal law, public law-private law. As elements themselves, there is reciprocal relationship between internal elements and external elements, called structure. These elements could be changed without obstructing the continuity of system. ${ }^{19}$

Legal system is conceptual, opened, continuous, consistent, and complete system. Legal system as conceptual system means that the system or the parts and elements themselves are invisible unity. We could not see the real one, but there is legal system. It's just as a concept, which can be read in writing. As opened system, legal system can affect and be affected some internal aspects, such as culture, economics, history, politics, etc. Besides, regulation can be interpreted differently, even though for some regulation cannot. The changing of viewpoints of values, definitions, or principles could influence the law but it does not change the system as unity. The system will be continuous. The conflict that arises in legal system will be settled by itself. The law expert, such as magistrates and rule maker, would find solution by creating main guide or completing the law by interpretation. The system will be consistent and complete thereof. ${ }^{20}$

\footnotetext{
${ }^{18}$ Sudikno Mertokusumo, Mengenal Hukum Suatu Pengantar, (Yogyakarta: Liberty, 2003), p. 122.

19 Ibid., p. 123.

${ }^{20}$ Ibid., pp. 124-126.
} 


\section{A. Islamic Law in Legal System}

\section{Indonesia experience}

Before Indonesia as occupied country, the Indonesian Muslim people obeyed and carried Islamic teaching into effect in their daily life. Islamic law as a part of Islamic teaching is obeyed and done as well. It can be seen that some kingdoms in Indonesia put Islamic law into force because the kings embraced to Islam, e.g., Kerajaan Samudera Pasai, Kesultanan Demak, Kesultanan Banten, etc. In some region, there were some courts, with different form, to solve disputes related to Islamic law among Muslim people. In some region, Aceh, Jambi, South Kalimantan, East Kalimantan etc, the magistrates were chosen by the kings or sultan, in others, Java, the courts were arranged by penghulu, the administrative officer of mosque. The names of Islamic courts were various, such as Pengadilan Surambi or veranda court (the meeting was held at veranda of mosque) in Java, Kerapatan Kadhi in Kalimantan, Mahkamah Syari'ah in Sumatera, and Majelis Syara' in South Sulawesi, Maluku and Irian (presently, Papua).

When Dutch occupied Indonesia, the Dutch law touched the effectiveness of Islamic law. The power of Dutch government in Indonesia was very forceful. It was implemented by the effectiveness of some regulations made by Dutch government, e.g., Compendium Freijer, Cirbonsh Rechtsboek, Compendium der Voornamste Javasche Wetten naukerig getrokken unit het Mohammedanche Wetboek Mogharraer, and Compendium Indlansche Wetten bij de Hoven van Bone en Goa. ${ }^{21}$ These regulations were a guide of government officer and dispute settlement of original people's law.

In the effectiveness of Dutch law for Indonesian people, there were two Dutch experts whose theories affected the law. They were Lodewijk Willem Christian van den Berg and Christian Snouck Hurgronje.

LWC van den Berg (1845 - 1927) in his theory of receptio in complexu points out that Islamic law holds for Muslim people completely even though there are deviations in implementation. This theory was written in the law of Staatsblad 1882 No. 152. The law determined that original people or occupied people were effected their religious law in their neighbors. This determination strengthened the existence of Islamic law in Muslim society and gave authority to Islamic courts to settle Islamic disputes in society. In Staatsblad 1885 No. 2 Article 75 and 78 determined that

Article 75 (3) Oleh Hakim Indonesia itu hendaklah diberlakukan undang-undang agama (godsdientige wetten) dan kebiasaan penduduk Indonesia itu.

[Indonesian magistrates shall put law of religious (godsdientige wetten) and Indonesian custom into force]

(4) Undang-undang Agama, instelling dan kebiasaan itu jugalah yang dipakai untuk mereka oleh hakim Eropa untuk pengadilan

${ }^{21}$ Ichtijanto, op.cit., p. 29. 
yang lebih tinggi andaikata terjadi hoger beroep atau pemeriksaan banding.

[The Act of religion, regulation and custom shall be used by European magistrates in appeal court]

Article 78 (2) Dalam hal terjadi perkara perdata antara sesama orang Indonesia itu atau dengan mereka yang dipersamakan dengan mereka, maka mereka tunduk kepada putusan hakim agama atau kepala masyarakat mereka menurut undang-undang agama atau ketentuan-ketentuan lama mereka. ${ }^{22}$

[In the matter of civil affair among Indonesian people or between Indonesian people and equalized people, they obey to decision of religious magistrates or head of society based on the act of religion or their old (custom) law]

Another theory gave a huge effect in Indonesian legislation is receptie theory of Christian Snouck Hurgronje. He argues that custom law or adat law is in effect for original people, Islamic law will be in effect if the norm of Islamic law has been accepted by society as adat law. This theory was based on Hurgronje's willing Islamic law not to be in effect because the law gave the followers impact not to be influenced by western civilization easily. Therefore, Hurgronje gave advices of "Islam Policy" to the government. ${ }^{23}$

1. In ritual activities, the government shall let them to do so freely.

2. In societal activities, the government shall respect adat law by direct them to receive Dutch law gradually and carefully.

3. In the field of state, the government should prevent the movement of Pan Islamisme to find other power to against the government.

This theory was written in an article, called receptie article, Article 134 IS (Indische Staatsregeling) in 1929. And the policy was implemented in some ways, i.e., the government put Wet Boek van Straafrecht from Netherlands into force as the Code of Criminal Law in Indonesia, prevented Islamic teaching of politics and state fields, and narrowed aspects of Islamic private law (mu'amalah) especially in heritage by delegating case of heritage to Land Raad (general court). In regard to delegation of heritage case from religious court to land raad, there was dialogue between the government and ulama (Muslim jurist scholar). As the result thereof, religious court has authority to publish fatwa of heritage, not decision. Fatwa is an Islamic legal opinion given by a Muslim jurist scholar as a response to a question. ${ }^{24}$ Practically, the amount of fatwa in religious court is bigger than decision in land raad or general court.

According to Hazairin, in the era of Indonesian independence when Indonesia has its own constitution, i.e., UUD 1945, the whole Dutch legislation is not valid any longer. It is due to the spirit of the legislation is not as same as the spirit of UUD 1945. In UUD 1945 stated that the independence of Indonesia from occupation. It as well

22 Ibid., p. 31.

${ }^{23}$ Ibid., p. 34.

${ }^{24}$ Mohamad Atho Mudzhar, "Fatwas of The Council of Indonesian Ulama A Study of Islamic Legal Thought in Indonesia 1975 - 1988”, Dissertation at University of California, 1990, p. 2. 
stated that the state is based on the sole of divinity. One of his interpretations of Article 29 of UUD 1945 that national legislation should not be contrary with religious teaching in Indonesia, i.e., Islam, Christian, Catholic, Hindu, and Buddha. In Islam, according to the al-Qur'an, Islamic law is in effect and must be performed by Muslim since he embraces to Islam, saying syahadat or creed. ${ }^{25}$ Thereby, the Article 134 IS, in this respect, is not valid any longer. Hazairin named the receptie theory of Hurgronje as demon theory because it asks Muslim people to follow the wrong way, the way against to Islamic teaching. He stated also that to put Islamic law into force formally, it should be based on legislation in Indonesia. ${ }^{26}$

Based on Hazairin's opinion, Sajuti Thalib analyzed much more deeply in the light of receptie theory. According to research in some provinces in Indonesia ${ }^{27}, \mathrm{He}$ pointed out of some opinions:

1. Islamic law is in effect to Muslim people.

2. This matter is in accordance with the faith and goals of law, spirit, and morality.

3. Adat law is in effect to Muslim people as long as not contrary to Islamic teaching and Islamic law.

Thalib called his opinion as theory of receptio a contrario, contradiction to receptie theory of Hurgronje. He supported Hazairin's opinion that the spirit of Indonesian society is on UUD 1945 which contradictory to Article 134 IS.

Currently, there are legislations influenced by Islamic law. They are Undangundang (Law) No. 1 Year 1974 about Marriage, Undang-undang No. 7 Year 1989 about Religious Court, Undang-undang No. 7 Year 1992 about Banking, Undang-undang No. 10 Year 1998 about The Changing of Undang-undang No. 7 Year 1992 about Banking, Undang-undang No. 38 Year 1999 about Zakat Management, Undang-undang No. 41 Year 2004 about Wakaf (Endowment), and Kompilasi Hukum Islam (Compilation of Islamic Law).

The Indonesian society willing of marriage law reflected on claim of women organizations to Volksraad (Board of People). The willing was based on some marital cases in society. Discussing this regard, the organizations held Congress of Indonesian Women in 1928. Then, the government edict Undang-undang No. 22 Year 1946 about Registration of Marriage, Divorce and Rujuk. The Law was not sufficed to satisfy the willing because it determined administrative regulation merely. Finally, the government tried to implement the marriage law. The process was long enough and full of debating. For instance, the argument of marriage registration as one of requirements of legal marriage, polygamy, minimum age to marriage, marriage between different religion, engagement, divorce, and adoption of child. ${ }^{28}$ Ulama, government, political parties, and organizations discussed and compromised material

${ }^{25}$ Hazairin, Tujuh Serangkai tentang Hukum, (Jakarta: Bina Aksara, 1981), p. 60.

${ }^{26}$ Sajuti Thalib, Receptio A Contrario: Hubungan Hukum Adat dengan Hukum Islam, (Jakarta: Bina Aksara, 1985), p. 59.

27 The research was carried out by Badan Pembinaan Hukum Nasional (BPHN) and Faculty of Law University of Indonesia in 1977/1978 at D.I. Aceh (presently Nangroe Aceh Darussalam), Jambi, Palembang, DKI Jaya (presently Jakarta), and West Java; in 1978/1979 at some cities, i.e., West Jakarta, Cirebon, Serang, Pekalongan, Semarang, Surabaya, Malang, Mataram, Nusa Tenggara Barat, and Banjarmasin; by BPHN and Faculty of Law University of Gadjah Mada in 1981 at South Kalimantan. See Thalib, ibid., pp. 66-79.

${ }^{28}$ Khoiruddin Nasution, Status Wanita di Asia Tenggara: Studi Terhadap Perundang-undangan Perkawinan Muslim Kontemporer di Indonesia dan Malaysia, (Jakarta: INIS, 2002), pp. 55-56. 
of draft of marriage law. Finally, the government legalized Undang-undang No. 1 Year 1974 about Marriage which be effective on October $1^{\text {st }} 1975$.

As explained previously that the religious court in Indonesia has been exist since Indonesian people converted to Islam. This court is very important for Muslim to settle dispute settlement among them. In 1970, it is mentioned on Undang-undang No. 14 Year 1970 about The Basis of Judicial Power that Religious Judicature system is one of judicature systems in Indonesia. Unfortunately, the Law determines this system implemented after 19 years. In this term, the religious court was still running, settling cases for Muslim. In 1989, Undang-undang No. 7 Year 1989 about Religious Court were implemented to regulate religious judicature system. The court has absolute competency to settle cases of marriage, heritage, wasiat (testament), hibah (charity gift), wakaf (endowment), and shadaqah (charity) based on Islamic law. Presently, in the process of amendment the Law, the competency is added with bank, institution of micro finance, insurance, re-insurance, reksadana, bond, security of middle-term, financing, pawning, pension fund, and business which all based on Islamic system. ${ }^{29}$

On the other side, the Law of Banking, UU No. 7 Year 1992 and UU No. 10 Year 1998, were no intrinsic. It is due to this law is needed by many people, Muslim and Non-Muslim. In 1992, UU No. 7 Year 1992 stated that there were two banking systems, riba $^{30}$ or interest system and profit-loss sharing system. It did not state Islamic banking system. The statement of profit-loss sharing system based on Islamic law stated on Peraturan Pemerintah (government regulation) No. 75 Year 1992. The existence of Islamic banking faced the monetary crisis in 1997-1998 proved the excellence of Islamic banking system. Then, Islamic banks grew in Indonesia. Regarding this situation, the government supported the system by promulgating the new law, UU No. 10 Year 1998. The system, not using interest system, developed to others conventional banks to use dual system. The support is not only the law but also the existence of Islamic Economics Institution. Majelis Ulama Indonesia (the Council of Indonesian Ulama) was asked to be involved in giving fatwa of transaction and controlling the Islamic banks through Dewan Syariah Nasional (National Syariah Board). The consequence, Islamic economics institutions are growing in Indonesia, e.g., Islamic insurance, Islamic pawning, and Islamic capital market. The effect of the institutions is positive for state and society.

Muslim people have on obligation to pay zakat. Zakat is the compulsory levy on the income and wealth of Muslims (satisfy certain requirements) for social welfare purposes in a broad sense (for certain people called mustahiq). Another Islamic social expenditure is wakaf. Wakaf is donation for religious (Islamic) purposes. Indonesian Muslim people have performed both social expenditures since a long time. Knowing and realizing the benefit of the expenditures for society and the state, the government edict Undang-undang No. 38 Year 1999 and Undang-undang No. 41 Year 2004. There were no hard contradictory for these law.

29 "Ada 11 Bidang Usaha Syariah yang Jadi Wewenang Pengadilan Agama", http://www.hukumonline.com/detail.asp?id=14528\&cl=Berita, accessed on March 17th 2006.

${ }^{30}$ Riba literally means an "addition" or an "increase" over and above the original size or amount. In Qur'anic terminology, it essentially refers to the practice of lending money for a prefixed rate of return or interest. See Irfan Ul Haq, Economic Doctrines of Islam: A Study in the Doctrines for Poverty, Employment and Economic Growth, (Virginia: International Institute of Islamic Thought, 1996), p. 117. 
Compilation of Islamic Law (KHI) is a compilation of legislation of Islamic law. There are three chapters on the compilation, i.e., marriage, heritage, and wakaf. The purpose of KHI is as unification of Islamic law and as legal power of judge's decision. ${ }^{31}$ This compilation is in effect solely for Muslim people. It is not Undang-undang or Law which part of Indonesian hierarchy of legislation. The effectiveness of the compilation was based on Instruksi Presiden (Instruction of President) No. 1 Year 1991 which suggested magistrates in Religious Court to use it. Previously, the magistrates used alQur'an, al-Hadits, yellow book (kitab kuning, is compilation of ulama's opinion regarding the law in al-Qur'an and al-Hadits) and Indonesian legislation. By the instruction, KHI became one of legal basis for magistrates in decision-making of cases; its legal existence of legislation notwithstanding is weak.

\section{Malaysia Experience}

History of Malaysian legal system was started before the coming of English. The custom law derives from original people who lived in Tanah Melayu in 3000 to 2000 B.C. ${ }^{32}$ The original people divided into three groups, i.e., Negrito, Senoi, and Melayu Asli. Each groups had own custom law, which be in effect until present.

The very legitimacy of the Malay Rulers was, and still is, bound up with both Islam and Malay cultural values. ${ }^{33}$

The coming of Islam had great influence to the law. The law was becoming combination of Islamic law and custom law.

The custom laws in Malaysia before the coming English were Adat Perpatuh for Melayu people in Negeri Sembilan and some Naning regions in Melaka, and Adat Temenggung in others region of Semenanjung. In Serawak, the Law was hard influenced by Islamic law, which written in Undang-Undang Mahkamah Melayu Serawak. ${ }^{34}$

In era of Kesultanan Melayu before western influence, Hukum Kanun Melaka dan UU Melayu Lama put into force. These Laws were based on adat law and Islamic law, especially in fields of marriage, trading (mua'amalah), and judicature. ${ }^{35}$ In the field of judicature, the dispute settlements were performed by kings, outstanding figure, and leader of village. ${ }^{36}$ The first written Undang-Undang Islam (Islamic Act) was Batu Surat, in Terengganu, which determined punishment of criminal based on alQur'an dan as-Sunnah. ${ }^{37}$ Then, others Laws emerged like Kanun Melaka in Melaka, Kanun Pahang in Pahang, and Undang-Undang Sembilan Puluh Sembilan in Perak.

In the era of English occupation, England implemented its legislation gradually. Firstly, the legislation was implemented in Negara-negara Selat, i.e., Pulau Pinang, Melaka and Singapura by Piagam Keadilan 1807. The contents were court

${ }^{31}$ Nasution, op.cit., p. 48.

${ }^{32}$ Noor Aziah Mohd Awal, Pengenalan Kepada Sistem Perundangan di Malaysia, (Selangor Darul Ehsan: International Law Book Services, 2004), p. 15.

${ }^{33}$ Kamali, op.cit., p. 6.

${ }^{34}$ Nasution, op.cit., p. 62.

${ }^{35}$ Ibid., pp. 62-63.

${ }^{36}$ Ibid., p. 63.

37 Ibid. 
determination and usage of English Law in court except concerning Islam and adat Melayu.

In 1880, Britain recognized the existence of marriage and divorce law by Mohamedan Marriage Ordinance No. V of 1880 about registration of marriage and divorce. Then, the ordinance was renewed for many times, i.e., Mohamedan Marriage Ordinance No. XIII of 1894, Ordinance No. XXXIV of 1902, The Mohamedan Marriage Ordinance 1908, The Muhammadan Marriage Ordinance No. XVII of 1909, The Muhammadan Marriage Ordinance No. 4 of 1917, Ordinance No. 26 of 1920, Ordinance No. 26 of 1923, Ordinance No. 26 Revised Law 1926, Ordinance of 1934, Chapter 57 Revised Law of Straits Settlement of 1936 in Mohammedans Ordinance 1936, and Ordinance 1940. In 1959, the independence of Negeri-negeri Selat made the new law, The Administration of Muslim Law Enactment 1959 No. 1, whereas The Administration of Muslim Law Enactment 1959 No. 3 were for Pulau Pinang. ${ }^{38}$

Negara-negara Melayu Bersekutu consists of Perak, Selangor, Negeri Sembilan, and Pahang. The influence of English legal system in Negara Melayu Bersekutu was started in Perak by Perjanjian Pangkor (Pangkor Agreement) of 1874. This agreement determined Pentadbiran Residen; function of resident was for giving advices to the kings to be performed except concerning religion and adat Melayu. Practically, there were deviations. Many English officers became judge in the court. On the other side, according to resident's advice, Sultan established Majlis Mesyuarat Negeri (Assembly Council) as advisor, but Sultan and the council published the new enacment as same as English enactment. Thus, Islamic law was formed in enactment.

The English judges in Malaysian court had important role in Malaysian legal system. In dispute settlement, the judge used English law if he could not find the regulation on written law in Malaysia. The Ordinance UU Sipil (Civil Law) of 1956 strengthened this means. It was stated on Section 3 that if there is no rule on the law, the judges use common law England, and on Section 5 that regarding trading use English enactment. ${ }^{39}$ Besides, the judges could use English law when they interpreted the written law of Malaysia. As a result, UU Islam implemented for certain cases in family law.

The first enactment for Negara-negara Melayu Bersekutu was Registration of Muhammadan Marriages and Divorces Enactment 1885. Then, the enactment was renewed repeatedly by some enactments. Finally, Selangor has The Administration of Muslim Law Enactment No. 3 of 1952, Negeri Sembilan has The Administration of Muslim Law Enactment No. 15 of 1960, and Pahang has The Administration of the Law of the Religion of Islam Enactment No. 12 of $1963 .{ }^{40}$

In Negara-negara Melayu Tidak Bersekutu, consists of Kelantan, Terangganu, Kedah, Perlis, and Johor, there were some enactments determined subjects in detail related to marriage and divorce based on Islamic law. English law was not accepted by legal system in these negeris, but the law was influenced informally through enactment based on English law and the judges had been trained in England. ${ }^{41}$ Covering a long process, Negara-negara Melayu Tidak Bersekutu united all of the

\footnotetext{
38 Ibid., pp. 69-70.

${ }^{39}$ Awal, op.cit., pp. 30 \& 36.

${ }^{40}$ Nasution, op.cit., hal. 72-77.

${ }^{41}$ Awal, op.cit., p. 28.
} 
enactments into one enactment. In Kelantan, there was The Council of Religion and Malay Custom and Kathis Court Enactment No. 1 of 1953. In Terengganu, there was The Administration of Muslim Law Enactment No. 2 of 1964. In Kedah, there was The Administration of Muslim Law Enactment No. 9 of 1962. In Perlis, there was Undangundang Pentadbiran Agama Islam No. 3 of 1964. And in Johor, theres was Enakmen Pentadbiran Agama Islam No. 14 of 1978.

In the era of independence, the enactment of marriage was legalized in each negeri. Then, each negeri reformed the enactment in accordance with its own purpose. For instance, Perak, Selangor, Negeri Sembilan and Akta Wilayah aims to change some determinations concerning marriage, divorce, allowance, child nursing, and other familial matters. Kedah aims to unite the enactment related to Islamic family concerning marriage, divorce, allowance, child nursing and other familial matters in order to bind Muslim. The purpose of Kelantan is to unite and to reform the enactment. ${ }^{42}$ Therefore, every negeri has its own enactment. The Islamic family enactments (UU Keluarga Islam) of each negeri are UU Keluarga Islam Melaka of 1983, Kelantan of 1983, Negeri Sembilan of 1983, Wilayah Persekutuan of 1984, Perak No. 1 of 1984, Kedah No. 1 of 1984, Pulau Pinang of 1985, Terengganu of 1985, Pahang No. 3 of 1987, Selangor No. 2 of 1989, Johor of 1990, Serawak of 1991, Perlis of 1992, and Sabah of $1992 . .^{43}$ There was an effort to unify UU Keluarga Islam by Tengku Zaid. Unfortunately, it did not work because not all of negeri accepted the whole contents of UU. Thus, UU Keluarga Islam are varied in Malaysia. ${ }^{44}$

Mahkamah Syariah is judicial institution, which has authority in dispute settlements of Islamic cases. There are three level of Mahkamah Syariah, i.e., Mahkamah Rendah Syariah, Mahkamah Tinggi Syariah, and Mahkamah Rayuan Syariah. The authority of Mahkamah Syariah is limited on family, wealth, and criminal. The subjects of family are heritage, engagement, marriage, divorce, dowry, allowance, child adoption, and child nursing. The subjects of wealth are wakaf (endowment), zakat mal and zakat fitrah, baitulmal, etc. The subjects of criminal are khalwat, astray teaching, not fasting, alcoholic drinking, zina (adultery and fornication), etc. In some negeris have Syariah Criminal Enactment, which regulate criminal law based on Islamic law. ${ }^{45}$

\section{Harmonization of Islamic Law in National Legal System}

Both colonial countries, Netherlands and England, have the same way to get heart and to control the occupied countries, Indonesia and Malaysia. Respecting and allowing the original law, i.e., Islamic law and adat law, to be performed by people. They let these laws live. Notwithstanding, Netherlands and England seemed to be worried with the existence of Islamic law towards their law. They thought that Islamic law would move their law. Therefore, they restricted the effectiveness of Islamic law in marriage and divorce merely. They knew that family law is the law lives in Muslim daily life, besides it is not easy to put away this law from Muslim. As the first step, they

\footnotetext{
42 Nasution, op.cit., p. 87.

${ }^{43}$ Ibid., pp. 85-86.

44 Ibid., p. 87.

${ }^{45}$ Awal, op.cit., pp. 78-79.
} 
only regulated registration of marriage and divorce. But, the needs of Muslim of the law was more than that, so the regulation broadened to the material of the law. At this regard, it could be concluded that Islamic law and western law are different.

Regarding colonial system in Indonesia, Soetandyo Wignjosoebroto explained

that

Pada era pascakolonial, berlakunya hukum yang berparadigma libertarian dengan doktrin-doktrinnya yang positivistis - disadari atau tidak - ternyata bertahan kuat sekalipun semangat dan sikap anti-Barat pada masa-masa pascakolonial itu demikian kuatnya. Ada semacam fakta pengakuan telah terjadinya biaya cultural yang besar sehingga penanganannya dengan memulai yang baru akan menghadapi perhitungan sunken cost yang tak tertanggungkan. Sekalipun pada tahun 1950-an berbagai pihak menyarankan dipertimbangkan model hukum nasional yang lain, entah bertolak dari asas-asas (paradigmatic?) hukum adat entah pula dari hukum Islam, dan bahkan presiden waktu itu juga mencanangkan perlunya dikembangkan system hukum revolusi, tidaklah semua mampu menggeser - apalagi menyingkirkan - dominasi ajaran hukum positif yang berkukuh menuruti konfigurasi ajarannya yang libertarian dan individualistis. ${ }^{46}$

I agree with Wignjosoebroto's opinion that colonial legal system is not easy to put away even though this system does not derive from Indonesian culture. Having colonial education influence the way of thinking and paradigm makes the followers preserve the system even though he is true Indonesian and or Muslim. It should be realized, as Khoirudin Nasution's opinion, that the effort of reformation of marriage law in Indonesia and Malaysia in colonial era loaded with, from, and for colonial interest. $^{47}$

The existence of Islamic law in Indonesia and Malaysia has similarity and differentiation. The similarities are:

1. The Muslim-majority in both countries pushes the government to put Islamic law into force.

2. Islamic law must be written into constitution or legislation. It is needed to have legal basis when performing Islamic law.

3. The existence of religious court is very important in dispute settlement related to Islamic law.

4. The influence of western legal system is very strong in national legal system. The problem is the western legal system is different from Islamic legal system.

5. Islamic law was implemented limitedly based on western legislation. It was limited to family law. Both countries have the same process, the colonial country in the beginning just determined registration of marriage and divorce. And the last, the law determined the material law. In this regard, it is still happening until now even though there are efforts to broaden subjects in legislation.

${ }^{46}$ Soetandyo Wignjosoebroto, Hukum: Paradigma, Metode dan Dinamika Masalahnya, (Jakarta: ELSAM dan Huma, 2002), pp. 90-91.

${ }^{47}$ Nasution, op.cit., p. 88. 
The differentiations are

1. The way of implementation of western legal system into national legal system.

2. The form of legislation. Indonesia has one legislation, which is in effect to all of Indonesian people. On the contrary, Malaysia has many enactments, which are different from one to the others in each negeri.

Up to now, western legal system (Dutch in Indonesia, English in Malaysia) still exists in both countries. Thus, national legal system of Indonesia and Malaysia consists of Islamic legal system, adat legal system, and western legal system.

\begin{tabular}{|c|c|c|}
\hline No & Subject & Malaysia \\
\hline 1 & External elements & $\begin{array}{l}\text { - Culture of society is varied } \\
\text { - Politics of colonizer (in the past) and of the } \\
\text { government } \\
\text { - Western education influence the way of thinking }\end{array}$ \\
\hline 2 & Internal elements & $\begin{array}{l}\text { - Values of Islamic teaching live in society } \\
\text { - Principles of Islamic law could not be changed } \\
\text { - Constitution preserves various legal system }\end{array}$ \\
\hline
\end{tabular}

\section{Conclusion}

Obligation of Muslim to obey Islamic teaching, especially Islamic law, has been accommodated in certain subjects, such as marriage law, heritage law, wakaf, zakat, economics law, and criminal law. By putting Islamic law into national legislation implicates Muslim people could perform two obligations, i.e., obey the law of God (Islamic law) and the law of state. Therefore, legislation as positive law is needed to harmonize the both systems. Notwithstanding this positive law consists of moral and divinity, not the norm of society only, because the Islamic law derives from law of God. This positive law could be functioned as convergence, where the society and the state recognized this positive law officially. At the same time, it is functioned to strengthen the existence of Islamic law and Islamic society in the state.

The divergence is the way or the process of convergence in accordance with own condition, such as structure of society, politics, willing, economics, culture, etc. Mohammad Hashim Kamali states his opinion of legal system in Malaysia (even though in this writing I do not explain political influence to existence of Islamic law, it is important to be known his opinion),

The most influential ingredient of this picture [a mixed picture of divergent influences that tend to pull the country in different directions], which has remained in the center-stage of Malaysian politics, is the multi-communal factor. ${ }^{48}$

The communal factor extends beyond relations among the ethnic groups and permeates the politics in each ethnic group, the Malays, Chinese and Indians. ${ }^{49}$

\footnotetext{
${ }^{48}$ Kamali, op.cit., p. 2

${ }^{49}$ Ibid., p. 3.
} 
This divergence does not mean to emerge gap between Muslim people and other religions, but to enrich science to get welfare and prosperity in the world.

\section{Bibliography}

\section{Books}

A., Ichtijanto S, 1990. Hukum Islam dan Hukum Nasional. Jakarta: Ind-Hill Co.

Ali, Abdullah Yusuf, 2003. The Holy Qur'an: Text and Translation, $5^{\text {th }}$ reprint. Kuala Lumpur: Islamic Book Trust.

Ali, Mohammad Daud, 2000. Hukum Islam: Pengantar Ilmu Hukum dan Tata Hukum Islam di Indonesia, Jakarta: RajaGrafindo Persada.

Awal, Noor Aziah Mohd, 2004. Pengenalan Kepada Sistem Perundangan di Malaysia.

Selangor Darul Ehsan: International Law Book Services.

Azhary, Muhammad Tahir, 2003. Negara Hukum: Suatu Studi tentang Prinsipprinsipnya Dilihat dari Segi Hukum Islam, Implementasinya pada Periode Negara Madinah dan Masa Kini. Bogor: Kencana.

Bowen, John R, 2003. Islam, Law, and Equality in Indonesia. Cambridge: Cambridge University Press.

Choudhury, Golam W., 1994. Islam and the Modern Muslim World. Kuala Lumpur: WHS Publications Sdn Bhd.

Haq, Irfan Ul, 1996. Economic Doctrines of Islam: A Study in the Doctrines for Poverty, Employment and Economic Growth. Virginia: International Institute of Islamic Thought.

Hazairin, 1981. Tujuh Serangkai tentang Hukum. Jakarta: Bina Aksara.

Kamali, Mohammad Hashim, 2000. Islamic Law in Malaysia: Issues and Developments. Kuala Lumpur: Ilmiah Publishers.

Lukito, Ratno, 1998. Pergumulan Antara Hukum Islam dan Adat di Indonesia. Jakarta: INIS.

Mertokusumo, Sudikno, 2003. Mengenal Hukum Suatu Pengantar. Yogyakarta: Liberty.

Mudzhar, Mohamad Atho, 1990. "Fatwas of The Council of Indonesian Ulama A Study of Islamic Legal Thought in Indonesia 1975 - 1988", Dissertation at University of California.

Nasution, Khoiruddin, 2002. Status Wanita di Asia Tenggara: Studi Terhadap Perundang-undangan Perkawinan Muslim Kontemporer di Indonesia dan Malaysia. Jakarta: INIS.

Thalib, Sajuti, 1985. Receptio A Contrario: Hubungan Hukum Adat dengan Hukum Islam. Jakarta: Bina Aksara.

Wignjosoebroto, Soetandyo, 2002. Hukum: Paradigma, Metode dan Dinamika Masalahnya. Jakarta: ELSAM dan Huma.

\section{Internet}

"Ada 11 Bidang Usaha Syariah yang Jadi Wewenang Pengadilan Agama”, http://www.hukumonline.com/detail.asp?id=14528\&cl=Berita, accessed on March 17th 2006. 
Bradley, David. "A Note on Comparative Family Law: Problems, Perspectives, Issues and Politics", <http://ouclf.iuscomp.org/articles/bradley2.shtml>, accessed on February 28th 2006.

<http://www.statistics.gov.my/english/frameset_product.php?file=list\&id=populatio $\mathrm{n}>$

"Islam in Southeast Asia at the Dawn of the 21st Century and Future Relations of Muslim Countries and East Asia", $<$ http://www.iiu.edu.my/rector/book/chapter5.html> accessed on February 28th 2006.

"Number of Population by Religion Year 2005", $<$ http://www.depag.go.id/index.php?menu=page\&pageid=17, accessed on March 2nd 2006.

Population and Housing Census 2000. Press Statement, "Population Distribution and Basic Demographic Characteristics Report Population and Housing Census 2000", Putrajaya $6^{\text {th }}$ November 2001, <http://www.statistic.gov.my/english/census/pressdemo.htm , accessed February 28th 2006. 